DOI https://doi.org/10.30525/978-9934-26-146-6-39

\title{
ПІДТРИМКА ПОЛІТИКИ АКАДЕМІЧНОЇ ДОБРОЧЕСНОСТІ ЯК ЧИННИК МОДЕРНІЗАЦІЇ УПРАВЛІНСЬКОЇ ДІЯЛЬНОСТІ В ЗАКЛАДАХ ВИЩОЇ ОСВІТИ
}

\author{
Петриченко Л. О. \\ доктор педагогічних наук, професор, \\ професор кафедри педагогіки, психології, початкової освіти \\ та освітнього менеджменту \\ Комунальний заклад «Харківська гуманітарно-педагогічна академія» \\ Харківської обласної ради \\ м. Харків, Украӥна
}

Сучасні трансформаційні процеси інтеграції системи вищої освіти України в європейський освітній простір передбачають грунтовні зміни як в підходах управління, так і в чинниках оцінювання ефективності управління освітніми процесами в закладах вищої освіти. Нові виклики для модернізації процесу управління були обумовлені не лише загальним реформами держави, а i пандемію COVID у 2019-2021 навчальних роках. Запроваджені карантинні обмеження, які обумовили постановку нових управлінських завдань, мали розв'язати основні проблеми організації безперервного освітнього процесу, забезпечити відділений доступ здобувачів освіти та менеджменту до освітнього процесу, забезпечити формування компетентностей у здобувачів освіти відповідно до освітніх програм.

Зазначимо, що однією із умов якісної освіти та управлінської діяльності в закладі освіти виступає «академічна доброчесність», політика підтримки якої та шляхи упровадження в закладі вищої освіти визначають не лише рейтинг, а і майбутнє системи освіти в закладі, регулюючи запит суспільства на освітні послуги в певному закладі освіти.

Відповідно до статті 42 Закону України «Про освіту», поняття «академічної доброчесності» розуміється як сукупність етичних принципів та визначених законом правил, якими мають керуватися учасники освітнього процесу під час навчання, викладання та провадження наукової (творчої) діяльності з метою забезпечення довіри до результатів навчання та/або наукових (творчих) досягнень [2].

Основні характеристики напрямів модернізації освіти на державному рівні представлено в наукових розвідках: А. Артюхова, В. Козакова, 
О. Комарова, С. Кравченко, В. Кременя, В. Лугового, І. Мищишина, С. Пазиніча, О. Пономарьова, А. Сбруєвої та інших.

Питання актуальності формування академічної чесності як критерію успішного розвитку закладу освіти досліджували : В. Банись, Б. Буяк, Н. Гапон, Г. Пономарьова, А. Харківська та інші.

Академічну доброчесність як складовий елемент освітнього середовища закладу освіти досліджували: Ю. Блудова, Г. Пономарьова, Л. Петриченко, О. Цокур, Т. Ярошенко та інші.

Таким чином, одним із сучасних чинників модернізації управлінської діяльності виступає рівень підтримки політики академічної доброчесності менеджментом закладу вищої освіти.

Зазначимо, що при розробці управлінських інструментів із урахуванням тенденцій щодо державного упорядкування підтримки політики академічної доброчесності, менеджментом закладу освіти ураховуються наступні фактори економічного впливу на якість іiі реалізації: загальні закони ринкової економіки, принципи конкурентоспроможності на ринку освітніх послуг у закладі вищої освіти; стан ринку праці в регіоні, його взаємозв'язок із стратегією розвитку закладу освіти; попит на професійні кадри певної спеціальності на ринку праці; перспективи розвитку певної галузі в системі вищої освіти [1].

Підтримка політики академічної доброчесності менеджментом закладу вищої освіти уособлює сучасні суспільні ідеали та цінності, визначає рівень престижності здобутої освіти.

Політичні процеси в країні також сприяють політиці підтримки академічної доброчесності менеджментом закладу вищої освіти, що полягають в підсиленні ролі громадських організацій та їх впливів на зміст освітньої політики, демократизацію суспільних процесів в освіті.

Поширення технічних інструментів та інформаційних новітніх технологій сприяло підтримці академічної доброчесності менеджментом закладу вищої освіти, що створило умови для формування академічної культури та академічної відповідальності всіх учасників освітнього процесу.

Отже, визначення змісту модернізації управлінської діяльності та рівня підтримки політики академічної доброчесності менеджментом закладу вищої освіти обумовлено: специфікою реалізації соціального, економічного, політичного, культурного розвитку держави; ресурсами створених матеріальних, фінансових, кадрових можливостей закладу вищої освіти; розробленою стратегією розвитку закладу вищої освіти; рівнем культурного освітнього простору створеного закладом вищої освіти; рівнем розвитку наукового потенціалу у закладі вищої освіти; 
принципами системи управління закладом вищої освіти, демократичності та прозорості його нормативно-правової бази. Зазначимо, що визначені умови $є$ динамічними, можуть змінюватись під впливом зовнішніх та внутрішніх факторів, процесів у державі, системі освіти, рисами управлінської діяльності в закладі освіти, специфікою надання освітніх послуг тощо [3].

На сучасному етапі підтримка політики академічної доброчесності як чинника модернізації управлінської діяльності в закладах вищої освіти може бути охарактеризована в наступному:

1. Розробка менеджментом закладу вищої освіти власної системи діагностики та оцінювання якості діяльності щодо підтримки політики академічної доброчесності на всіх рівнях.

2. Створення відповідних структурних підрозділів, що регламентують та контролюють процес дотримання принципів академічної доброчесності учасниками освітнього процесу відповідно до норм закону.

3. Зміна кадрової політики менеджментом закладу вищої освіти відповідно до критерію дотримання принципів академічної доброчесності професорсько-викладацьким складом та здобувачами освіти.

4. Демократизація процесу управління та створення умов для реалізації стратегії розвитку закладу освіти із дотриманням принципів академічної доброчесності, визначення пріоритетності упровадження політики академічної доброчесності менеджментом закладу вищої освіти.

5. Створення сприятливого психологічного клімату в колективі, умов для наукового пошуку, взаємодопомоги, зацікавленості в результатах всіма учасниками освітнього процесу із дотриманням принципів академічної доброчесності.

6. Варіативність процесу управління у ході підтримки політики академічної доброчесності, що передбачає упровадження моделі, системи управлінської діяльності, коригування мети відповідно до результатів діагностики та якості дотримання принципів академічної доброчесності учасниками освітнього процесу.

7. Трансформація методів управлінської діяльності в закладах вищої освіти від прямого впливу до опосередкованого моделювання управлінських систем та інструментів їх реалізації. Уникнення формальності в процесі обгрунтування вимог щодо дотримання принципів академічної доброчесності учасниками освітнього процесу.

8. Розробка механізмів залучення до управлінської діяльності як членів академічної та наукової спільноти, так і всіх зацікавлених сторін. 
9. Упровадження способів самоорганізації, децентралізації управлінської діяльності в закладах вищої освіти, які відповідають вимогам часу, і запиту суспільства та держави.

Зважаючи на процеси модернізації управлінської діяльності у ході підтримки політики академічної доброчесності менеджментом закладу вищої освіти, Законом передбачено обов'язкове притягнення до академічної відповідальності науково-педагогічних працівників шляхом: відмови у присудженні наукового ступеня чи присвоєнні вченого звання; позбавленні присудженого наукового ступеня чи присвоєного вченого звання; відмова у присвоєнні або позбавленні присвоєного педагогічного звання, кваліфікаційної категорії; позбавлення права займати визначені законом посади. Для здобувачів освіти: повторне оцінювання; повторне проходження частини освітньої програми; відрахування із закладу вищої освіти; позбавлення академічної стипендії; позбавлення пільг з оплати за навчання, якщо такі надані за результатом академічних успіхів здобувача освіти.

Отже, модернізація управлінської діяльності на сучасному етапі будується за міжнародними стандартами, та передбачає створення оптимальних умов для впровадження кращих зарубіжних практик щодо підтримки політики академічної доброчесності менеджментом закладу вищої освіти.

\section{Література:}

1. Аналіз провідного вітчизняного та зарубіжного досвіду щодо механізмів реалізації ефективного врядування в університетах: аналітичні матеріали Ч ІІ. за заг. ред. С. Калашнікової. Київ: Інститут вищої освіти НАПН України, 2019. 96 с.

2. Про освіту: Закон України «Про освіту». Відомості Верховної ради України. 2019. № 2657-VIII. 2661 - VIII. URL: https://zakon.rada.gov.ua/laws/show/2145-19\#Text. (дата звернення: 20.09.2021).

3. Пономарьова Г. Ф., Петриченко Л. О., Харківська А. А., Бабакіна О. О., Єрьомкін А. І., Акімова О. М. Управління освітнім процесом у закладах вищої освіти: робочий зошит. Комунальний заклад «Харківська гуманітарно- педагогічна академія» Харківської обласної ради. Харків, 2019. 57 с. 